\title{
The comparative analysis of morphological and functional indicators of armwrestling and street workout athletes
}

\author{
Olha O. Podrihalo ${ }^{1 \mathrm{ABCDE}}$, Leonid V. Podrigalo ${ }^{1,2 \mathrm{ABCDE}}$, Sergiy V. Kiprych ${ }^{3 \mathrm{BDE}}$, Mycola I. Galashko ${ }^{1 \mathrm{BDE}}$, \\ Anatoliy F. Alekseev ${ }^{1 \mathrm{BDE}}$, Yuri M. Tropin ${ }^{1 \mathrm{BDE}}$, Alfiia Kh. Deineko ${ }^{1 \mathrm{BDE}}$, Mykhailo K. Marchenkov ${ }^{1 \mathrm{BDE}}$, \\ Olena Yu. Nasonkina ${ }^{1 \mathrm{BDE}}$ \\ ${ }^{1}$ Kharkiv State Academy of Physical Culture, Kharkiv, Ukraine \\ ${ }^{2}$ V. N. Karazin Kharkov National University, Ukraine \\ ${ }^{3}$ Poltava V.G.Korolenko National Pedagogical University, Ukra. D)
}

Authors' Contribution: A - Study design; B - Data collection; C - Statistical analysis; D - Manuscript Preparation; E - Funds Collection.

\section{Abstract \\ Background and Study Aim \\ Material and Methods}

Results

Conclusions:

Keywords:
The purpose of the work is a comparative analysis of morphological and functional indicators and characteristics of the somatotype of armwrestling athletes and street workout athletes.

The study involved Street Workout athletes (StW, $\mathrm{n}=15$, age $-14.87 \pm 0.42$ years, training experience $1.48 \pm 0.22$ years) and armwrestling athletes ( $\mathrm{ArW}, \mathrm{n}=11$, age $-14.87 \pm 0.42$ years, training experience $-1.48 \pm 0.22$ years). The body length and body mass were determined. The level and harmony of physical development were assessed by the regression method. Handgrip was assessed in a static mode. The electronic handgrip dynamometer Camry EH101 (China) was used. The handgrip is determined by the maximum frequency of the grip in $10 \mathrm{~s}$. The electronic device "Kepai" (China) was used to measure it. The content of muscle and adipose tissue, the level of visceral fat were determined. The body structure monitor OMRON BF-511 (Japan) was used. The handgrip index, hand impulse index, static and dynamic handgrip index were calculated. Differences were assessed using the Rosenbaum test (Q).

A high level of handgrip was determined for all athletes. The average value of the strength index was the StW group - more than $60 \%$ of body mass; the ArW group - more than $70 \%$ of body mass. The following indicators were observed in the ArW group: harmonious physical development had $(27.27 \pm 13.43) \%$ of athletes; disharmony due to excess body mass had $(45.45 \pm 15.01) \%$ of athletes; disharmony due to body mass deficit had ( $27.27 \pm 13.43) \%$ of athletes; normal fat content had (63.64 \pm 14.50$) \%$ of athletes; low-fat content had $(18.18 \pm 11.63) \%$ of athletes; high and high-fat content had $(9.09 \pm 8.67) \%$ of athletes. The ArW group was characterized by high $-(50.00 \pm 15.81) \%$, high $-(40.00 \pm 15.49) \%$, and normal $-(10.00 \pm$ 9.49)\%-the specific weight of muscle tissue. In the StW group, the following indicators were observed: harmonious physical development had $(46.67 \pm 12.88) \%$ of athletes; disharmony due to excess body mass had $(53.33 \pm 12.88) \%$ of athletes; normal fat content had $(57.14 \pm 13.23) \%$ of athletes; low-fat content had $(42.86 \pm 13.23) \%$ of athletes. All athletes in the StW group had a high proportion of muscle tissue. It was found that exercises with your body mass in a street workout decreased fat content compared to armwrestling.

The results confirmed the specific effect of the sport on the body of athletes. Handgrip should be considered as a success predictor in these sports. The information content of the proposed handgrip indices for monitoring the functional state of athletes was confirmed. armwrestling, street workout, physical development, somatotype, bioimpedance method, handgrip.

\section{Introduction}

Martial arts and strength sports are traditionally the most popular among young people. Martial arts form the physical and psychological qualities of athletes; the worldview of youth [1]. The young generation has a growing need for an athletic and well-built body. Therefore, the number of people involved in various power sports (bodybuilding, powerlifting, arm wrestling), as well as the recently appeared street workout, is increasing. Mulyk et al. [2] investigated the popularity of fitness programs among students. The most popular are strength and Martial arts: Crossfit Training, Kickboxing,

\footnotetext{
(c) Olha O. Podrihalo, Leonid V. Podrigalo, Sergiy V. Kiprych, Mycola I. Galashko, Anatoliy F. Alekseev, Yuri M. Tropin, Alfiia Kh. Deineko, Mykhailo K. Marchenkov,

Olena Yu. Nasonkina, 2021

doi:10.15561/26649837.2021.0307
}

Tabata Training, Body Sculpt, Barbell Workout.

Improving one's command of his or her own body can dramatically improve movement quality, and performance [3]. Bodyweight exercises allow athletes to improve how they manipulate their bodies through space in a way that is both important for health and difficult to replicate with other training methods that do not always accommodate a client's unique anthropometry. The street workout is a unique sport in this context. This type of exercise is based on the use of your body mass and allows optimizing the muscle mass [4].

Taipe-Nasimba et al. [5] studied the psychosocial profile of Street Workout athletes. It was concluded that this sport is beneficial for enhancing physical activity. It improves opportunities for social inclusion. The advantages also include low economic cost and 
affordability for the population. The analysis of the main psychological characteristics of Street Workout athletes made it possible to determine the fact that this sport is dominated by men under the age of 23; the main motivation of men is taking care of their health and their appearance [6].

Determination of the morphological characteristics of the most popular sports allows assessing and comparing athletes. It is valuable for improving their results. Chernozub et al. [7] confirmed the positive influence of strength exercises on morphometric indicators and adaptive-compensatory capabilities of female athletes. The study of physical development peculiarities allows assessing the specificity of the influence of the kind of sport on the body of athletes [8]. The use of special indices allows highlighting the features and qualities that are predictors of success in different types of Martial arts.

Recently, there has been a growing interest in the analysis of the morphological status and body structure. Body shape and morphology are the main factors determining athletic performance [9]. Thus, the diagnosis of somatotype and anthropometric characteristics are often the subject of research for a certain population group [10]. Because of its uniqueness, the somatotype has been used to study many aspects of exercise, sports science, and human biology. It is important for identifying talented young athletes in specific sports [11].

The purpose of the research is a comparative analysis of anthropometric indicators and somatotype of workout and armwrestling athletes.

\section{Material and Methods}

\section{Participants.}

The study involved 26 street workout (StW) and armwrestling (ArW) athletes. The athletes were divided into two groups. The StW group included 15 Street Workout athletes (age $14.87 \pm 0.42$ years). The ArW group included 11 armwrestling athletes (age $18.50 \pm$ 0.43 years). The average work experience was in the $\mathrm{StW}$ group - $1.48 \pm 0.2$ years; in the ArW group - $2.35 \pm 0.33$ years. Differences between the groups in age and training experience are significant $(\mathrm{p}<0.05)$.

Research Design

The research design involved the determination of anthropometric indicators, somatotype components, and the calculation of indices using special formulas. The research program and design were discussed and approved at The Meeting of Bioethics Commission of Kharkiv State Academy of Physical Culture (record from 04/12/2021).

The calculation of body mass and body length was conducted according to international standards [12]. Martin's medical anthropometer was used to calculate body length $(\mathrm{cm})$. Body composition monitor OMRON BF-511 (Japan) was used to calculate body mass ( $\mathrm{kg}$ ). The assessment of the harmony of physical development level was conducted by the regression method using official standards for children [13] and adults [14].

The handgrip $(\mathrm{kg})$ was calculated in a static mode by dynamometry. CAMRY EH101 electronic hand dynamometer was used (China). The handgrip is determined by the maximum grip frequency in the impulse mode (abs). The electronic device "Kepai" (China) was used. The technique assumed the maximum number of device grip in $10 \mathrm{~s}$. One grip was equivalent to a force of $10 \mathrm{~kg}$.

The somatotype was assessed using the bioimpedance method. The body composition monitor OMRON BF511 (Japan) was used. The specific weight of muscle and adipose tissue (\%), the level of visceral fat (\%), the amount of basal metabolism (kcal) were determined. The analysis of somatotype components was assessed according to the Omron Healthcare scale and the recommendations of Doskin et al. [15].

The following morphofunctional indices were calculated:

Strength index $(\%)$ - the ratio of handgrip indicators $(\mathrm{kg})$ to body mass $(\mathrm{kg})$.

Impulse index (\%) - the ratio of the maximum frequency of the handgrip in impulse mode in $10 \mathrm{~s}$ (abs) to body mass $(\mathrm{kg})$.

Static and dynamic grip index is the ratio of handgrip $(\mathrm{kg})$ to the maximum frequency of the handgrip in impulse mode in $10 \mathrm{~s}$ (abs).

Statistical Analysis.

Statistical analysis was performed using licensed MS Excel. The following indicators are determined by descriptive statistics: arithmetic mean (M), standard deviation, and mean error (m). Due to the small number of groups, the reliability of the differences was assessed using a nonparametric indicator - the Rosenbaum criterion $(\mathrm{Q})$; differences were considered significant at $(\mathrm{p}<0.05)$.

\section{Results}

The results are shown in Table 1.

The results of the table illustrate the high level of handgrip strength in all participants: the average value of the strength index in the StW group was more than $60 \%$ of the body mass, and in the ArW group - more than 70\% of the body mass.

Significant differences were found between the groups. The ArW group characterized by excess body length $(\mathrm{Q}=$ $8)$, handgrip of the right hand $(\mathrm{Q}=7)$ and left hand $(\mathrm{Q}=$ 12), the level of visceral fat $(\mathrm{Q}=10)$, strength index of the right $(\mathrm{Q}=19)$ and left hand $(\mathrm{Q}=26)$, impulse index of the right hand $(\mathrm{Q}=13)$ and left hand $(\mathrm{Q}=15)$, static and dynamic handgrip index of the right hand $(\mathrm{Q}=12)$.

The physical development level in the ArW group was determined: average, high, and below-average had $(27.27 \pm 13.43) \%$ of athletes; above-average had (18.18 $\pm 11.63) \%$ of athletes. The following indicators were determined: $(27.27 \pm 13.43) \%$ of athletes had harmonious physical development; disharmony due to excess body mass had $(45.45 \pm 15.01) \%$ of athletes and due to a deficiency in body mass had $(27.27 \pm 13.43) \%$ of athletes.

In the StW group, the average level of physical development was $(53.33 \pm 12.88) \%$ of athletes, above the average - $(20.00 \pm 10.33) \%$, below the average and high 
Table 1. Indicators of physical and somatotype development of armwrestling athletes and street workout athletes

\begin{tabular}{lll}
\hline Indices & StW (n=15) & ArW (n=11) \\
\hline Body length, $\mathrm{cm}$ & $170.53 \pm 2.70$ & $180.60 \pm 2.21$ \\
Body mass, $\mathrm{kg}$ & $64.58 \pm 3.95$ & $74.00 \pm 4.39$ \\
Handgrip of right hand, $\mathrm{kg}$ & $40.03 \pm 2.70$ & $53.01 \pm 4.66$ \\
Handgrip of left hand, kg & $38.52 \pm 2 / 37$ & $52.00 \pm 4.01$ \\
Maximum grip frequency in pulse mode of the right hand, number of times & $26.73 \pm 2.59$ & $32.40 \pm 1.65$ \\
Maximum grip frequency in pulse mode of the left hand, number of times & $23.93 \pm 2.92$ & $28.60 \pm 2.01$ \\
The specific weight of adipose tissue,\% & $12.95 \pm 8.97$ & $14.41 \pm 11.11$ \\
The specific weight of muscle tissue,\% & $41.81 \pm 13.18$ & $43.01 \pm 15.66$ \\
The value of the main metabolism, kcal & $1697.93 \pm 49.02$ & $1734.00 \pm 65.09$ \\
The specific weight of visceral fat,\% $\%$ & $4.11 \pm 6.28$ \\
Right hand strength index,\% $\%$ & 0 & $72.59 \pm 13.45$ \\
Left hand strength index,\% & $63.25 \pm 12.89$ & $70.91 \pm 13.69$ \\
Impulse index of the right hand, $\mathrm{kg}^{-1}$ & $60.63 \pm 13.06$ & $44.42 \pm 14.98$ \\
Impulse index of the left hand, $\mathrm{kg}^{-1}$ & $39.60 \pm 13.07$ & $38.96 \pm 14.70$ \\
Static and dynamic handgrip index of the right hand, $\mathrm{kg}$ & $36.04 \pm 12.83$ & $1.66 \pm 0.15$ \\
Static and dynamic handgrip index of the left hand, $\mathrm{kg}$ & $1.57 \pm 0.09$ & $1.89 \pm 0.19$ \\
\hline
\end{tabular}

level according to $(13.33 \pm 8.78) \%$. $(46.67 \pm 12.88) \%$ of athletes had harmonious physical development. Disharmony due to excess body weight was observed in $(53.33 \pm 12.88) \%$ of athletes.

The analysis of the somatotype characteristics according to the Omron Healthcare scale determined that in the StW group $(57.14 \pm 13.23) \%$ of the athletes had a normal fat content, $(42.86 \pm 13.23) \%$ of the athletes had a low-fat content. All athletes in this group had a high specific weight of muscle tissue. In the ArW group, the normal fat content had $(63.64 \pm 14.50) \%$ of athletes, low fat content had $(18.18 \pm 11.63) \%$ of athletes, high and high-fat content had $(9.09 \pm 8.67) \%$ of athletes. Athletes in this group were characterized by high $(50.00$ $\pm 15.81) \%$, high $(40.00 \pm 15.49) \%$, and normal $(10.00 \pm$ $9.49) \%$ specific weight of muscle tissue.

Basal metabolic results in the groups did not differ significantly.

\section{Discussion}

The study of the influence specificity of a kind of sport on the athletes' body is one of the important tasks of sports science. It allows optimizing the process of sports selection, to improve the effectiveness of the success' prediction and skills development in certain sports. Identification of success predictors can significantly improve the performance of athletes. Research results have confirmed the importance of many factors in this context. Chernenko et al. [16] confirmed the existence of a correlation between the typological characteristics of the nervous system and the high sports achievements of wrestlers. The authors recommended using functional mobility of the central nervous system as criteria for assessing the prospects of wrestlers.

Jagiello et al. [17] investigated the body structure of athletes of the Polish women's national fencing team. The specificity of the athletes' body structure engaged in saber fencing has been determined. It is concluded that there is a correlation with the long-term effects of training, as well as with the selection of athletes with specific somatic prerequisites.

The importance of studying the characteristics of athletes' body structure is confirmed in the works of Jagiello et al. [17-19]. The use of the Percala method of natural indicators made it possible to determine in the Martial arts athletes the most important functions for achieving success. The results allow optimizing the training process.

The studies based on comparing the characteristics of athletes in various sports are widespread. The choice of armwrestling and Street Workout for comparison is due to their strength orientation. Both sports require a strong handgrip to be successful. It predetermined the developed research program aimed at studying the strength of the hand muscles.

A similar research design was used in the study of Kharisov et al. [20, 21] The authors compared the anthropometric indicators and the somatotype composition of students in powerlifting and workout. Volodchenko et al. [22] conducted a comparative analysis of the psychophysiological status of athletes involved in various types of Martial arts. The highlighted features are interpreted from the standpoint of the athlete's skills development. Methods for their assessment are proposed to be used in monitoring the functional state of Martial art athletes.

A similar set of techniques was used in the study by Podrihalo et al. [23] Comparison of the results of armwrestlers with different skill levels confirmed the importance of developing hand muscles and body structure for achieving success in this sport. The parallel study of handgrip in static and dynamic modes is important in armwrestling. The success in this sport is determined by the strength and maximum speed of the handgrip.

Participants belong to different age groups. Athletes in the StW group are in puberty and prepubertal period, 
which is characterized by intensive development of the body. The ArW athletes are in a more stable condition. On the one hand, different periods cause differences in functional performance. Alternatively, the differences increase against the background of intense strength training. It is why indices were used. These indicators are relative values and allow for standardizing the factors under study.

The index method is widely used in sports science. The calculation and analysis of indices allow simply, quickly, and visually assess the features of the physical development and functional state of athletes. Currently, the indices are used in complex systems for assessing health and physical fitness. The informativeness of indices in armwrestling has been proven. The effectiveness of predicting the performance of athletes in this sport was confirmed using indices [24].

Methods for assessing muscle strength and body composition are used to assess the effectiveness of training in sports and recreational activities. Kalwa et al. [25] used a similar design to assess the performance of people over 40 years of age. Confirmed an increase in hand strength, a decrease in body mass and adipose tissue, an improvement in physical fitness and body mobility. Feito et al. [26] used similar techniques to analyze the adaptation to highintensity training. Mandaric and Sibinovic [27] evaluated the effectiveness of workout training in water in terms of strength and body structure.

In our study, high values of the strength index of athletes reflect the importance of handgrip in both sports. In armwrestling, a strong and high-quality handgrip increases the likelihood of winning the fight. Podrihalo et al. [23] assessed this indicator as one of the success predictors. The results of Podrigalo et al. [24] confirmed the informativeness and significance of the strength index for assessing handgrip. Simultaneously, a handgrip in Street Workout is important for the technical performance of apparatus exercises. A high-quality handgrip serves not only to optimize the technique but also to prevent injuries in this sport.

However, one strength index is not enough to assess the handgrip. It led to the development of other indices given in this research. The impulse index is an indicator that we proposed by analogy with the strength index. It illustrates the handgrip in impulse mode relative to body mass. The results of Iermakov et al. [28] confirmed the informative value of the maximum handgrip frequency in an impulse mode for predicting success in martial arts. This technique was used to analyze the armwrestler state with different skill levels [23]. The use of the index in the form of a relative indicator allows to increase the visibility and information content of the results; use the results in monitoring the functional state of athletes.

We have proposed another indicator for analyzing the results - it is the index of the static and dynamic handgrip. In our opinion, this index reflects the potential ability of hand muscles to work in different modes - static and dynamic. The large value of this index among athletes of the ArW group is another proof of the importance of handgrip strength for success in this sport.

The study of the influence of morphological characteristics on success in sports allows to draw up specification equations for a particular sport and contribute to a more adequate modeling of athletes' actions [29].

The analysis of physical development is an effective tool for assessing the athletes' state. In the ArW group, athletes were almost equally divided according to average, high, and below-average levels of physical development. The group is dominated by participants with disharmonious physical development. Almost 50\% of the disharmony was due to overweight. In the context of using the bioimpedance method, it reflects an increase in the specific weight of muscle tissue. It is a consequence of the intense strength training typical of armwrestling.

Deviations from the average physical development in athletes of the StW group were less expressed. Among them, athletes with an average level of development prevailed. In terms of harmony, the athletes were divided almost equally. Simultaneously, disharmony was due only because of excess body weight. It should also be assessed as an illustration of the increase in muscle tissue content.

The assumptions made earlier were confirmed by the results of the bioimpedance method. It can be argued that there is a tendency to exceed the number of athletes with normal fat content compared to athletes with lowfat content in the StW group. Simultaneously, all athletes in this group characterized by a high content of muscle tissue. In the ArW group, the distribution of athletes was more complicated. The vast majority of athletes had normal body fat content. The vast majority of armwrestlers $(90 \%)$ had high levels of muscle tissue. Similar results are presented in the study by Kharisov et al. [20,21] compared Street Workout athletes with powerlifters. Powerlifters are characterized by a more developed chest, a stronger body structure, and a larger biceps stroke. Workout athletes have a more developed ideal body structure compared to powerlifters. Powerlifting athletes are characterized by a significantly higher body mass index, body fat.

The results of the somatotype analysis illustrate the specificity of the influence of the sport on the athletes' bodies. Arm wrestling and street workout strength sports. It leads to intense strength training. This approach increases the specific weight of muscle tissue.

Results of Sanchez-Martinez et al. [30] confirmed that Street Workout athletes have a balanced mesomorphic somatotype; low-fat mass; high muscle development with a predominance of the shoulders and trunk. The value of the body composition indices allows such athletes to be classified as a low-risk group for chronic non-infectious diseases.

Street workout includes exercises with a body, and exercises with weights are common in armwrestling. In both cases, your body mass is a factor in achieving success. In armwrestling, increasing body mass allows developing more strength in a fight. In the street workout, reducing body mass allows exercising with less effort. It is precisely what the established features of the somatotype of athletes reflect. 
The closeness of the results of the basal metabolic rate illustrates the similarity of the metabolic features of athletes, which are characteristic of power loads.

\section{Conclusion}

The comparative analysis of morphological and functional indicators and somatotype features of armwrestling and Street Workout athletes confirmed the specific influence of the sport on the athletes' organism. All athletes are characterized by an increased specific weight of muscle tissue. The information content of the proposed indices, characterizing the handgrip in the impulse mode, has been confirmed. It is recommended to use it in monitoring the functional state of athletes. The handgrip should be considered a success predictor of street workout and armwrestling. Indicators and indices of handgrip strength allow to adequately assess the athletes' state. The analysis of the athletes' physical development also confirms the specificity of the sport influence. Exercising with your body mass in the Street Workout decreased fat content compared to arm wrestling.

\section{Acknowledgments}

The authors express their gratitude to the public organization "Barstylers", trainer Nahorniuk Vladyslav, president Krylenko Ivan for help in organizing the research.

\section{Conflict of interests}

The authors declare no conflict of interest.

\section{References}

1. Blach W, Korobeynikov G, Vences de Brito A, Warchol $\mathrm{K}$, Cynarski WJ. Brief review of scientific events and publications -in the sphere of human and cultural problems, and martial arts discourse 2020. Ido Movement for Culture Journal of Martial Arts Anthropology, 2021;21:56-66. https://doi.org/10.14589/ido.21.1.8

2. Mulyk K, Maksimova K, Mulyk V. Motivational Principles of Using Various Fitness Programs. Research Journal of Pharmaceutical Biological and Chemical Sciences. 2018; 9(6): 673-680.

3. Langton B, King J. Utilizing body weight training with your personal training clients. ACSMS Health \& Fitness Journal. 2018; 22(6): 44-51. https://doi.org/10.1249/FIT.0000000000000433

4. Dudziak T, Czubek Z, Grabowski M, Urbanski R, Sawczyn S. Changes in body composition of children aged of 9 to 12 years with excess body weight under the influence of eight-week workout. Baltic Journal of Health and Physical Activity, 2018;10:89-95. https://doi.org/10.29359/BJHPA.10.3.10

5. Taipe-Nasimba N, Peris-Delcampo D, Canton E. Motives for sports practice, psychological well-being and immigration in Street Workout practitioners. Revista de Psicologia del Deporte. 2019;28(2): 135-141.

6. Taipe-Nasimba N, Chirivella CE. Street Workout: Psychosocial Profile of its Practitioners. Revista Internacional de Medicina y Ciencias de la Actividad Fisica y del Deporte. 2020; 20(79): 521-534. https://doi.org/10.15366/rimcafd2020.79.009

7. Chernozub A, Imas Y, Korobeynikov G. The influence of dance and power fitness loads on the body morphometric parameters and peculiarities of adaptive-compensatory reactions of organism of young women. Journal of Physical Education and Sport. 2018;18(2):955-960. https://doi.org/10.7752/jpes.2018.02141

8. Podrigalo L, Cynarski WJ, Rovnaya O, Volodchenko O, Halashko O, Volodchenko J. Studying of physical development features of elite athletes of combat sports by means of special indexes. Ido Movement for Culture Journal of Martial Arts Anthropology, 2019:51-7. https://doi.org/10.14589/ido.19.1.5

9. Matković BR, Mišigoj-Duraković M, Matković B, Janković S, Ružić L, Leko G, Kondrič M. Morphological Differences of Elite Croatian Soccer Players Accordning to the Team Position.Coll. Antropol. 2003;27(1): 167-174.
10.Joksimović M, Skrypchenko I, Yarymbash K, Fulurija D, Nasrolahi S, Pantović M. Anthropometric characteristics of professional football players in relation to the playing position and their significance for success in the game. Pedagogics, Psychology, Medical-Biological Problems of Physical Training and Sports, 2019;23(5):224-30. https://doi.org/10.15561/18189172.2019.0503

11.Carter JEL, Ackland TR, Kerr DA, Stapff AB. Somatotype and size of elite female basketball players. Journal of Sport Sciences, 2005;23(10): 1057-1063. https://doi.org/10.1080/02640410400023233

12.Marfell-Jones M, Olds T, Stewart A, Lindsay Carter LE. ISAK manual, International standards for Anthropometric Assessment. In International Society for the Advancement of Kinanthropometry. Published by The international society for the advancement of kinanthropometry, The University of South Australia Holbrooks Rd, Underdale, SA, Australia; 2012.

13.Serdiuk AM. Standards for assessing the physical development of schoolchildren. Kiev; 2010. (in Ukrainian).

14.Tegako LI, Marfina OV. Practical anthropology. Rostov on Don: Phoenix; 2003. (in Russian).

15.Doskin VA, Keller Kh, Muraenko NM, Tonkova-Yampolska RV. Morphofunctional constants of the child's body. Moscow: Medicine; 1997. (In Russian).

16. Chernenko N, Lyzohub V, Korobeynikov G, Potop V, Syvash I, Korobeynikova L, Kostuchenko V. Relation between typological characteristics of nervous system and high sport achieving of wrestlers. Journal of Physical Education and Sport, 2020;20(3):1621-1627. https://doi.org/10.7752/jpes.2020.03221

17.Jagiełło W, Marina J, Maciej KR, Jan BB, Artur L, Jarosław K. Properties of body composition of female representatives of the Polish national fencing team the sabre event. Biology of Sport. 2017;34(4):401-406. https://doi.org/10.5114/biolsport.2017.70526

18.Jagiello W. Perkal's method of natural indicators in the assessment of internal proportions of body composition in persons practising combat sports - a review. Archives of Budo.2019; 15:187-193.

19.Jagiello W, Dornowski M, Jagiello M. Perkal's natural indicators method in assessing body composition properties in persons practising combat sports - an analysis research results. Archives of Budo Science of Martial Arts and Extreme Sports. 2018;14: †75-80.

20.Kharisov I, Nenasheva A. Physical fitness of students 
practicing various artistic gymnastic routines. Minerva Ortopedica e Traumatologic. 2018; 69(3): 49-54.

21.Kharisov ID, Nenasheva AV, Aminov AS e.a. Assessment of physical fitness indicators in students practicing powerlifting and streetworkout.Human SportMedicine. 2017;17(1):67-78. https://doi.org/10.14529/hsm170107

22.Volodchenko O, Podrigalo L, Aghyppo O. Comparative Analysis of a functional state of martial arts athletes. Journal of Physical Education and Sport. 2017;17(4SI):2142 -2147. https://doi.org/10.7752/jpes.2017.s4220

23.Podrihalo OO, Podrigalo LV, Bezkorovainyi DO, Halashko OI, Nikulin IN, Kadutskaya LA, et al. Analysis of grip strength and somatotype features of armwrestling athletes of different skill levels. Physical Education of Students. 2020;24(2):120-126. https://doi.org/10.15561/20755279.2020.0208

24.Rovnaya O, Podrigalo L, Iermakov S, Yermakova T, Potop V. The Application of the Index Method to Assess the Condition of Armwrestling Athletes with Different Levels of Sports Mastery. Revista Romaneasca pentru Educatie Multidimensionala. 2019;11(4SI):242-256. https://doi.org/10.18662/rrem/187

25.Kałwa M, Stefaniak T, Harmaciński D, Groffik B. A preparation cycle in strength training as a form of health training for adults. Balt J Health Phys Act, 2019; 11(1): 62-75. https://doi.org/10.29359/BJHPA.11.1.07

26.Feito Y, Hoffstetter W, Serafini P, Mangine G. Changes in body composition, bone metabolism, strength, and skill-specific performance resulting from 16-weeks of HIFT. PLoS ONE, 2018;13(6): e0198324. https://doi.org/10.1371/journal.pone.0198324

27.Mandaric S, Sibinovic A. Water Workout Application Effects on the Body Composition and Motor Abilities of 13-Year-Old Female Adolescents. International Journal of Morphology. 2018;36(2): 629-634. https://doi.org/10.4067/S0717-95022018000200629

28.Iermakov SS, Podrigalo LV, Jagiełł Wł. Hand-grip strength as an indicator for predicting the success in martial arts athletes. Arch Budo. 2016; 12: 179-186.

29.Gardašević N, Fulurija D, Joksimović M, Eler N, Ahmedov FS. The Influence of Morphological Characteristics on Throw Speed in Handball. International Journal of Physical Education, Fitness and Sports. 2020; 9(3): 32-38. https://doi.org/10.34256/ijpefs2035

30.Sanchez-Martinez J, Plaza P, Araneda A, Sánchez P, Almagiâ A. Morphological characteristics of Street Workout practitioners. Nutricion Hospitalaria. 2017;34(1): 122-127 https://doi.org/10.20960/nh.987

\section{Information about the authors:}

Olha O. Podrihalo; http://orcid.org/0000-0003-1519-5632; rovnayaolga77@ukr.net; Kharkiv State Academy of Physical Culture; Klochkovskaya str. 99, Kharkiv, 61022, Ukraine.

Leonid V. Podrigalo; (Corresponding Author); http://orcid.org/0000-0002-7893-524X; leonid.podrigalo@gmail.com; Kharkiv State Academy of Physical Culture; Klochkovskaya str. 99, Kharkiv, 61022, Ukraine.

Sergiy V. Kiprych; https://orcid.org/0000-0002-9226-5713; kiprych@ukr.net; Poltava V.G.Korolenko National Pedagogical University; Ostroqradskogo str. 2, Poltava, 36000, Ukraine.

Mycola I. Galashko: http://orcid.org/0000-0002-7708-9504; nicolaygalashko@gmail.com; Kharkiv State Academy of Physical Culture; Klochkovskaya str. 99, Kharkov, 61022, Ukraine.

Anatoliy F. Alekseev; http://orcid.org/0000-0001-8018-170X; af.aleks38@gmail.com; Kharkiv State Academy of Physical Culture; Klochkovskaya str. 99, Kharkiv, 61022, Ukraine.

Yuri M. Tropin; https://orcid.org/0000-0002-6691-2470; tropin.yuri@gmail.com; Kharkiv State Academy of Physical Culture; Klochkovskaya str. 99, Kharkiv, 61022, Ukraine.

Alfiia Kh. Deineko; https://orcid.org/0000-0001-7990-7999: udeineko@gmail.com; Kharkiv State Academy of Physical Culture; Klochkovskaya str. 99, Kharkiv, 61022, Ukraine.

Mykhailo K. Marchenkov; https://orcid.org/0000-0002-7640-8972; marchenkov.mihail@gmail.com; Kharkiv State Academy of Physical Culture; Klochkovskaya str. 99, Kharkiv, 61022, Ukraine.

Olena Yu. Nasonkina; https://orcid.org/0000-0002-6127-932X; nasonkinaelena@gmail.com; Kharkiv State Academy of Physical Culture; Klochkovskaya str. 99, Kharkiv, 61022, Ukraine.

Cite this article as:

Podrihalo OO, Podrigalo LV, Kiprych SV, Galashko MI, Alekseev AF, Tropin YM, Deineko AKh, Marchenkov MK, Nasonkina OYu. The comparative analysis of morphological and functional indicators of armwrestling and street workout athletes. Pedagogy of Physical Culture and Sports, 2021;25(3):188-193.

https://doi.org/10.15561/26649837.2021.0307

This is an Open Access article distributed under the terms of the Creative Commons Attribution License, which permits unrestricted use, distribution, and reproduction in any medium, provided the original work is properly cited (http://creativecommons.org/licenses/by/4.0/deed.en).

Received: 10.05 .2020

Accepted: 24.06.2021; Published: 30.06.2021 